\title{
Civic-Minded Graduate: Additional Evidence II
}

\section{Robert G. Bringle}

Indiana University Purdue University Indianapolis

\section{Thomas W. Hahn}

Indiana University Purdue University Indianapolis

Julie A. Hatcher

Indiana University Purdue University Indianapolis

\section{Recommended Citation:}

Bringle, R. G., Hahn, T. W., \& Hatcher, J. A. (2019). Civic-minded graduate: Additional evidence II. International Journal of Research on Service-Learning and Community Engagement, 7(1), Article 3. 


\title{
Civic-Minded Graduate: Additional Evidence II
}

\author{
Robert G. Bringle \\ Thomas W. Hahn \\ Julie A. Hatcher \\ Indiana University Purdue University Indianapolis
}

\begin{abstract}
The civic-minded graduate (CMG) construct provides a set of common learning objectives that can guide the design, implementation, and assessment of curricular and co-curricular civic engagement programs. The relationships of civic-mindedness with measures of various components of the CMG conceptual domain were examined in two studies. Study 1 found bivariate correlations for CMG with openness to diversity, self-efficacy, both social-change and charity orientations to service, and endorsement of the principle of care. Study 2 found $\mathrm{CMG}$ to be correlated with non-prejudicial attitudes and self-confidence for social behaviors. These confirmations of predicted conceptual relationships between CMG and components of its nomological network support CMG's validity and its usefulness as a superordinate educational objective for service-learning courses and programs with civic-learning outcomes. Implications for practice and future research are explored.
\end{abstract}

Keywords: civic learning, civic-minded graduate, civic-mindedness, service-learning

Higher education is increasingly expected to provide and support both curricular and co-curricular programs to graduate individuals who are committed to lifelong habits of civic engagement (Bringle, Games, \& Malloy, 1999; Colby, Ehrlich, Beaumont, \& Stephens, 2003; Percy, Zimpher, \& Brukardt, 2006; Saltmarsh \& Hartley, 2012). Battistoni (2002) identified 12 different meanings of citizenship, civic education, and associated civic skills, each linked to a cluster of disciplines and professions: (a) liberalism, (b) communitarianism, (c) participatory democracy, (d) public work, (e) social capital, (f) civic professionalism, (g) social responsibility, (h) social justice, (i) connected knowing and the ethic of care, (j) public leadership, (k) public intellectual, and (1) engaged or public scholarship. The civicminded graduate $(\mathrm{CMG})$ construct integrates various conceptualizations of civic-learning outcomes (Bringle, Brown, Hahn, \& Studer, in press; Bringle \& Steinberg, 2010; Bringle, Studer, Wilson, Clayton, \& Steinberg, 2011; Bringle \& Wall, in press; Hemer \& Reason, 2017; Steinberg, Hatcher, \& Bringle, 2011). A CMG is defined as:

a person who has completed a course of study (e.g., bachelor's degree), and has the capacity and desire to work with others to achieve the common good. "Civic-Mindedness" refers to a person's inclination or disposition to be knowledgeable of and involved in the community, and to have a commitment to act upon a sense of responsibility as a member of that community. (Bringle \& Steinberg, 2010, p. 429)

Civic-mindedness is viewed as distinct from orientations that emphasize one's self, family, or a corporate or profit motive. The CMG construct is composed of 10 attributes within four conceptual domains (Steinberg et al., 2011):

\section{Knowledge}

1. Volunteer Opportunities: understanding of ways to contribute to society, particularly through voluntary service, and including knowledge of nonprofit organizations. 
2. Academic Knowledge and Technical Skills: understanding of how knowledge and skills in at least one discipline are relevant to addressing issues in society.

3. Contemporary Social Issues: understanding of current events and the complexity of issues in modern society locally, nationally, or globally.

\section{Skills}

4. Communication and Listening: ability to communicate (written and oral) with others, as well as listen to divergent points of view.

5. Diversity: understanding the importance of, and the ability to work with, others from diverse backgrounds; also appreciation of and sensitivity to diversity in a pluralistic society.

6. Consensus-Building: ability to work with others, including those with diverse opinions, and work across differences to come to an agreement or solve a problem.

\section{Dispositions}

7. Valuing Community Engagement: understanding the importance of serving others, and being actively involved in communities to address social issues.

8. Self-Efficacy: having a desire to take personal action, with a realistic view that the action will produce the desired results.

9. Social Trustee of Knowledge: feeling a sense of responsibility and commitment to use the knowledge gained in higher education to serve others.

\section{Behavioral Intentions}

10. A stated intention to be personally involved in community service in the future. (p. 22)

The attributes of CMG were selected to capture civic outcomes for both curricular servicelearning and co-curricular programs that have civic learning as a focus (Bringle et al., 2011; Bringle et al., in press). Steinberg et al. (2011) used three different methods for measuring CMG: (a) a CMG Scale, which consists of 30 items; (b) a CMG Narrative, which produces a written narrative that is scored with a CMG rubric; and (c) a CMG Interview protocol, which is scored with a CMG rubric. Generally, these three assessment strategies have demonstrated convergence in measuring CMG. In addition, the CMG Scale was found to have a non-significant correlation with social desirability and a significant positive correlation with Morton's conceptualization of integrity (Bringle, Hatcher, \& MacIntosh, 2006), which measures the degree to which civic values and civic behaviors are aligned and integrated with one's self. Bringle and Wall (in press) offered research evidence on relationships between identity as a student and CMG; between civic identity and CMG; between CMG and all of the motives for volunteering on the Volunteer Functions Inventory (VFI; Clary et al., 1998); and between CMG and measures of interest in charity, service programs, and advocacy.

The present research complements and extends evidence for CMG by Steinberg et al. (2011) and Bringle and Wall (in press) and offers additional evidence and further understanding of the nature of CMG through two studies. Measures in the research were selected from the attributes posited to be part of the nomological network of CMG. A nomological network consists of relationships between observable properties to each other, relationships between theoretical constructs to each other, and relationships between theoretical constructs to observables (Cronbach \& Meehl, 1955). The 10 attributes in the four domains (i.e., knowledge, skills, dispositions, and behavioral intentions) identified for $\mathrm{CMG}$ constitute its nomological network. 


\section{Study 1}

Further assessing the theoretical validity of CMG, Study 1 examined two additional domains posited to be part of the CMG nomological network: (a) skills and attitudes toward diversity, and (b) selfefficacy. Concerning diversity, the conceptualization of CMG implicated diversity in two domains: (a) diversity as related to communication skills, and (b) "understanding the importance of, and the ability to work with, others from diverse backgrounds; also appreciation of and sensitivity to diversity in a pluralistic society" (Steinberg et al., 2011, p. 22). Because models of contemporary civic engagement and service-learning aspire to be democratic (i.e., inclusive, participatory, and fair; Saltmarsh, Hartley, \& Clayton, 2009), the most civically oriented individuals in this study were expected to have a positive orientation to issues related to diversity.

Regarding self-efficacy, service-learning students are often faced with complex and unpredictable challenges during community-engaged activities that require them to take action to make contributions in effective ways, overcome obstacles, and collaborate with others to reach intended goals. Eyler (2000) suggested that the way students approach these activities may be related to general self-efficacy. Astin and colleagues (2000) found that service-learning increased personal efficacy. In addition, self-efficacy may be a crucial factor in determining who can persist and thrive when engaging in community service: Those who do not have a sense of accomplishment may be more likely to stop volunteering. Therefore, in Study 1, it was expected that self-efficacy would correlate with CMG.

Bringle and Wall (in press) found that CMG was correlated with all three types of service that were posited by Morton (1995): charity (providing direct service to another person), project (implementing or participating in service programs through community-service organizations), and social change (transformational models of systemic change). Study 1 reexamined this finding by incorporating alternative measures of interest in charity activities and interest in social-change activities to determine if the correlations found in Bringle and Wall could be replicated. In addition, values from the VFI were found to be associated with CMG in Bringle and Wall and Steinberg et al. (2011). An alternative measure of values - the principle of care (Bekkers \& Ottoni-Wilhelm, 2016) - was included in Study 1, with the expectation that prior results correlating CMG and values would be replicated.

\section{Methods}

Sample. A stratified random sample of 1,772 undergraduate and graduate students enrolled at Indiana University Purdue University Indianapolis (IUPUI) was generated, and the first half of that sample was contacted for Study 1 through campus email addresses and invited to participate in an online survey. The larger sample was stratified by class (first year through graduate) to include students who had not completed a survey during the previous academic year. Additionally, to oversample civically engaged students, eight students were approached in the common area of IUPUI's Center for Service and Learning and asked to complete the survey. Potential respondents in Study 1 were told:

The purpose of this study is to survey students using multiple scales to assess the frequency, motivations, and attitudes toward civic engagement and complete the validation of the Civic-

Minded Graduate scale. This survey also includes questions regarding college experiences, education, and personality traits.

The survey was confidential. However, identifying information was collected to randomly draw a winner of $\$ 100$ from among the survey participants, and that information was disaggregated from the data analyses and reports. Due to the purpose of the study, the only requirement for participation was that each respondent be a college student 18 years or older. A total of 180 respondents $(68 \%$ female, $32 \%$ male) completed the questionnaire. Six percent of respondents were first-year students, $7 \%$ were second-year students, $11 \%$ were third-year students, $21 \%$ were seniors, $48 \%$ were graduate 
students, and $7 \%$ were non-degree students. Seventy-five percent of the sample comprised Caucasian students, and 96\% were commuter students. The mean age was 36 , and the median age was 32 .

Questionnaire. The first section of the questionnaire contained single items measuring some demographic information and frequency of political involvement during the previous four years (e.g., worked on a political campaign, assisted with voter registration); community involvement through campus organizations or clubs; service through community organizations; and the number of servicelearning courses taken during college. The single question measuring participation in servicelearning courses was, "How many service learning courses have you taken during your college years?" Respondents were provided with four response options (None, 1-2, 3-4, and 5 and above).

CMG Scale. The CMG Scale (Steinberg et al., 2011) was included in the questionnaire. The scale comprises 30 items that sample the 10 attributes in four domains: knowledge, skills, dispositions, and behavioral intentions. For this survey, a 6-point response scale was used (Strongly Disagree to Strongly Agree); however, items were rewritten from the original format used in Steinberg et al. (2011), and respondents were asked to respond to items for all of their college experiences, not just their experiences at a specific university as was done in Steinberg et al. A sample question was, "My college education has given me the professional knowledge and skills that I need to help address community issues." Coefficient alpha measures the internal consistency and reliability of a multi-item scale. The CMG Scale had a coefficient alpha of .97 in the current study, which was comparable to the coefficient alpha of .96 in Steinberg et al.

Openness to Diversity and Challenge Scale. The Openness to Diversity and Challenge Scale (Pascarella, Edison, Nora, Hagedorn, \& Terenzini, 1996) was developed as part of the National Study of Student Learning (Pascarella et al., 1996; Whitt, Edison, Pascarella, Terenzini, \& Nora, 2001). The 7-item scale assesses students' attitudes toward interacting with people from different backgrounds; openness to cultural and racial diversity; and the extent to which they enjoy being challenged by different perspectives, values, and ideas. A sample item on the scale is, "I enjoy having discussions with people whose ideas and values are different from my own" (Pascarella et al., 1996, p. 179). Responses are on a 5-point item-response scale (Strongly Disagree to Strongly Agree). In the current study, this scale had a coefficient alpha of .86 .

Charity Scale and Social Change Scale. A measure of interest in volunteering to help others through charity was included. It contained all four items from Moely, Furco, and Reed (2008) and two items from Wang and Jackson (2005) on a 5-point scale (Not at All to Great Extent). The measure of interest in advocacy and social change consisted of all four items from Moely et al. and two items from Wang and Jackson (2005). All items from Moely et al. in both scales contained the introductory phrase, "In the past 12 months." The coefficient alpha for the 6-item measure of interest in charity was .84 in this study, and for the 6-item measure of advocacy it was .87 .

Self-Efficacy Scale. The Self-Efficacy Scale (Sherer et al., 1982) consists of 30 items on a 5point item-response scale (Disagree Strongly to Agree Strongly) related to respondents' ability to master a number of different situations. A sample item is, "When I make plans, I am certain I can make them work" (Sherer et al., 1982, p. 666). Twenty-three items constitute the scale along with seven filler items. This scale had a coefficient alpha of .87 in the current research.

Principle of Care Scale. The Principle of Care Scale (Bekkers \& Ottoni-Wilhelm, 2016: Wilhelm \& Bekkers, 2010) consists of eight items on a 5-point item-response scale (Strongly Disagree to Strongly Agree) that explore the proposition that "helping behavior is also a consequence of an internalized moral value that one should help those in need" (Bekkers \& OttoniWilhelm, 2016, p. 240). Sample items in the scale include, "People should be willing to help others who are less fortunate" (Bekkers \& Ottoni-Wilhelm, 2016, p. 243). This scale had a coefficient alpha of .80 in the current research.

\section{Results}

Bivariate correlations were computed to assess the relationships between CMG and Diversity, 
Charity, Social Change, Principle of Care, Self-Efficacy, age, gender, college class, social network, and number of service-learning courses taken (see Table 1). There were large positive correlations between CMG and Diversity, CMG and Social Change, and CMG and Charity. There were moderate correlations between CMG and Principle of Care, CMG and Self-Efficacy, and CMG and number of service-learning courses taken, the latter indicating that those reporting having taken more servicelearning classes had higher CMG scores.

Table 1: Correlations for CMG, Diversity, Social Change, Charity, Principle of Care, SL Courses Taken, Self-Efficacy, Gender, College Class, Social Network, and Age in Study 1

\begin{tabular}{|c|c|c|c|c|c|c|c|c|c|c|}
\hline Measure & 1 & 2 & 3 & 4 & 5 & 6 & 7 & 8 & 9 & 10 \\
\hline 1. $\mathrm{CMG}$ & - & & & & & & & & & \\
\hline 2. Diversity & $.61 * *$ & - & & & & & & & & \\
\hline 3. Social Change & $.59 * *$ & $.40 * *$ & - & & & & & & & \\
\hline 4. Charity & $.54 * *$ & $.34 * *$ & $.75^{* *}$ & - & & & & & & \\
\hline 5. Principle of Care & $.42 * *$ & $.44 * *$ & $.21 * *$ & $.32 * *$ & - & & & & & \\
\hline 6. SL Courses Taken & $.32 * *$ & $.22 * *$ & $.36^{* *}$ & $.30 * *$ & .12 & - & & & & \\
\hline 7. Self-Efficacy & $.31 * *$ & $.29 * *$ & $.26^{* *}$ & $.28 * *$ & $.38 * *$ & .11 & - & & & \\
\hline 8. Gender & .10 & -.04 & .02 & .11 & .06 & .05 & -.04 & - & & \\
\hline 9. College Class & .04 & .05 & $.15^{*}$ & $.24 * *$ & .14 & .02 & -.02 & $.22 *$ & - & \\
\hline 10. Age & -.04 & 0 & .03 & .11 & .24 & .11 & $.17^{*}$ & $.20 * *$ & $.20 * *$ & - \\
\hline
\end{tabular}

A stepwise multiple regression was performed, with $\mathrm{CMG}$ as the dependent variable and age, gender, class in college, social network, number of service-learning courses taken, Charity, Social Change, Principle of Care, Self-Efficacy, and Diversity as the predictors. Table 2 contains the details of the regression analysis (only significant variables are included in the table). Diversity, Social Change, Principle of Care, and number of service-learning courses taken were independent predictors of CMG.

Table 2. Stepwise Regression Analysis Summary for Variables Predicting CMG in Study 1

\begin{tabular}{|c|c|c|c|c|c|c|c|c|c|c|}
\hline \multirow{2}{*}{ Variable } & \multicolumn{2}{|c|}{ Step 1} & \multicolumn{2}{|c|}{ Step 2} & \multicolumn{2}{|c|}{ Step 3} & \multicolumn{2}{|c|}{ Step 4} & \multicolumn{2}{|c|}{ Step 5} \\
\hline & B & $\boldsymbol{\beta}$ & B & $\boldsymbol{\beta}$ & B & $\boldsymbol{\beta}$ & B & $\boldsymbol{\beta}$ & B & $\boldsymbol{\beta}$ \\
\hline Constant & .263 & & .156 & & -.614 & & -.721 & & -.486 & \\
\hline Diversity & $.983 * *$ & 59 & $.733 * *$ & .44 & $.614 * *$ & .369 & $.598 * *$ & .359 & $.559 * *$ & .336 \\
\hline $\begin{array}{l}\text { Soc. } \\
\text { Change }\end{array}$ & & & $.388 * *$ & .41 & $.376^{* *}$ & .394 & $.335^{* *}$ & .351 & $.330 * *$ & .346 \\
\hline $\begin{array}{l}\text { Principle } \\
\text { of Care }\end{array}$ & & & & & $.309 *$ & .167 & $.311^{*}$ & .168 & $.402 *$ & .218 \\
\hline $\begin{array}{l}\text { SL } \\
\text { Courses }\end{array}$ & & & & & & & $.152 *$ & 131 & $.170^{*}$ & .146 \\
\hline
\end{tabular}


Table 2. Stepwise Regression Analysis Summary (cont'd)

\begin{tabular}{|c|c|c|c|c|c|c|c|c|c|c|}
\hline \multirow{2}{*}{ Variable } & \multicolumn{2}{|c|}{ Step 1} & \multicolumn{2}{|c|}{ Step 2} & \multicolumn{2}{|c|}{ Step 3} & \multicolumn{2}{|c|}{ Step 4} & \multicolumn{2}{|c|}{ Step 5} \\
\hline & B & $\boldsymbol{\beta}$ & B & $\boldsymbol{\beta}$ & B & $\boldsymbol{\beta}$ & B & $\boldsymbol{\beta}$ & B & $\boldsymbol{\beta}$ \\
\hline Age & & & & & & & & & $-.013 *$ & -.138 \\
\hline$R^{2}$ & .349 & & .491 & & .513 & & .528 & & .545 & \\
\hline $\mathrm{F}$ & $80.90 * *$ & & $72.41 * *$ & & $52.37 * *$ & & $41.41 * *$ & & $35.21 * *$ & \\
\hline$\Delta R^{2}$ & .349 & & .142 & & .022 & & .015 & & .017 & \\
\hline$\Delta F$ & $80.90^{* *}$ & & $41.96 * *$ & & $6.76^{*}$ & & $4.65^{*}$ & & $5.44^{*}$ & \\
\hline
\end{tabular}

Note. ${ }^{*} p<.05 . * * p<.001$

\section{Discussion}

Study 1 confirmed two additional attributes of the CMG nomological network: Attitudes toward diversity and caring were associated with scores on the CMG Scale. Concerning diversity, past research has found that civic outcomes included reduced stereotypes (Catlett \& Proweller, 2011; Eyler \& Giles, 1999; Teranishi, 2007) and an appreciation for diversity (Jones \& Hill, 2001). Brandenberger and Bowman (2015) found that diversity experiences were particularly important to prosocial growth from college entry through the junior year. As Pascarella et al. (2014) noted:

Our findings with an objective, standardized measure of critical thinking skills essentially support the conceptual argument ... that exposure to diversity experiences fosters the development of cognitive growth and more complex modes of thought. The cognitive effect of diversity experiences appears to be sustained during 4 years of college and may even increase in magnitude over time. (p. 90)

This supports the interdependent nature of CMG and attitudes toward diversity in the conceptual framework and suggests that pedagogical experiences that incorporate diversity, such as servicelearning, can foster the enhancement of other components of the CMG domain and other academic outcomes (e.g., critical thinking). In addition, these outcomes can have long-lasting consequences. For example, participation in a racial/ethnic student organization predicted community leadership experiences, donations to nonprofit and political organizations, and volunteering six years after graduation (Bowman, Park, \& Denson, 2015). Richard, Keen, Hatcher, and Pease (2016) found that dialogue across differences as part of the Bonner Scholars program during college was associated with post-graduation civic involvement, suggesting that co-curricular civic programs can also contribute to enduring civic-mindedness.

Astin and Sax (1998) found that 38\% of more than 3,000 college students surveyed engaged in service in order to "work with people who are different than me" (p. 255). Although this was not a motivation for a majority, there is clearly interest among some college students to be engaged with diverse others. This percentage also illustrates that there is room for educators to design courses that provide opportunities for other students to have educationally meaningful diversity experiences and to develop appreciation for how diversity can contribute to their worldview. Bowman (2011), in a meta-analysis, found that face-to-face diversity experiences (vs. didactic educational experiences) were related to increased civic attitudes. Thus, service-learning courses and co-curricular civic programs are particularly well-suited for developing deeper appreciation for diversity among those for whom it may not be salient by intentionally incorporating diversity experiences in communityservice activities and identifying learning objectives associated with diversity in reflection activities. These can focus on attributes of democratic civic values, such as freedom and dignity, empathy, open-mindedness, tolerance, justice, promoting equality, and social responsibility (National Task 
Force, 2012; Torney-Purta, Cabrera, Roohr, Liu, \& Rios, 2015).

Empathy has been identified as an important situation-specific emotional state that predicts helping and altruistic behaviors (Batson \& Ahmed, 2009). Bekkers and Ottoni-Wilhelm (2016) presented the case that empathy may be a powerful predictor of helping close others (e.g., family, friends, in-group members; also see Bloom, 2016; Konrath \& Grynberg, 2013). By contrast, Bekkers and Ottoni-Wilhelm (2016) viewed the principle of care, which is an internalized moral value that one should help those in need (Eisenberg, 1982), as a more powerful determinant of helping behaviors that are based on deliberative decision making and that benefit recipients who are in outgroups or only known in the abstract. Bekkers and Ottoni-Wilhelm presented results that support the principle of care as a stronger determinant (vs. dispositional empathy) of helping abstract others with monetary donations and that the principle of care mediated the relationship between dispositional empathy and giving. The finding that those scoring higher on CMG also scored higher on the principle of care and Bringle and Wall's (in press) finding that the Value motive was a significant correlate of $\mathrm{CMG}$ are consistent with the presumption that civic-minded persons possess the value of broadly caring about and having humanitarian concern for others. Bekkers and Ottoni-Wilhelm noted that "those interested in the development of helping behavior-families, schools, community organizations, religious congregations, etc.- - should take steps to ensure that an orientation toward empathic concern develops further into a principle of care (Eisenberg, 1982)" (p. 41). Thus, community-engaged activities, key academic content, and structured critical reflection activities that are focused on both empathy and the principle of care can be viewed as complementary aspects of course design that can enhance students' subsequent civic engagement.

Concerning the bivariate correlation of CMG and self-efficacy, research has demonstrated that "expectations of personal efficacy determine whether coping behavior is initiated, how much effort will be expended, and how long it will be sustained in the face of obstacles and aversive experience" (Bandura, 1977, p. 191). Within the context of civic engagement, the finding that civically minded students also scored higher on general self-efficacy is consistent with the interpretation that these individuals think they can make a difference in general and presumably through their communityservice activities. This is in contrast to Bringle, Hedgepath, and Wall (2018), who found no correlation between self-efficacy and empathic anger, an attribute associated with social change and concerns about injustice. Astin and colleagues (2000) found that service-learning facilitated increases in one's sense of personal efficacy, and Sanders, Oss, and McGeary (2016) found that structured reflection (vs. non-structured reflection) resulted in increased self-efficacy. The finding for self-efficacy in the current study was also consistent with Bringle and Wall's (in press) finding that CMG was correlated with protective motivation (Clary et al., 1998) for engaging in service. Protective motivation captures the capacity for community service to benefit the helper, namely by assisting in coping with stress.

This research used a measure of generalized self-efficacy. Previous research has conceptualized efficacy within the framework of community service and has developed validated tools for further research (Reeb, 2006; Reeb, Katsuyama, Sammon, \& Yoder, 1998). Future research could explore this measure's relationship to CMG. Furthermore, poor matching of service activities with students' skills can erode motivation and result in frustration. Thus, good course design should include matching competencies needed in a service site to the student's existing skills and motives so that a sense of self-efficacy is cultivated in service-learning courses (Clary et al., 1998; Houle, Sagarin, \& Kaplan, 2010; Moely et al., 2008).

The results of Study 1 also demonstrated the robustness of the finding that civic-minded students were interested in both charity and social-change types of community involvement. Study 1 used a different measure of motivation for both types of service and replicated the results of Bringle and Wall (in press), who found that CMG correlated with students' interest in charity, program, and advocacy types of service. This supports the conclusion that the most engaged students are not limited to a preference of one type of community involvement and may even see the connections between and the complementary nature of directly helping individuals, organizing others, working 
through nonprofit agencies, and producing systemic change to alleviate some of the causes of social circumstances for disadvantaged or marginalized people (Bringle et al., 2006). In addition, results of both Bringle and Wall (in press) and Study 1 found advocacy/social change to be a strong predictor of CMG in the regression analyses. Thus, the most civically engaged respondents and those with the greatest integration of civic with self were also engaged in communities in order to make a broad systemic difference.

\section{Study 2}

Study 2 explored other attributes in the nomological network of CMG. Service experiences often place students in communities with people of different ethnicities, backgrounds, circumstances, attributes, or socioeconomic status. As Dewey (1938) indicated, these experiences can have educative or miseducative outcomes. Using intergroup contact theory (Allport, 1954; Pettigrew \& Tropp, 2008), Erickson and O'Connor (2000) analyzed how service-learning courses can contain the attributes that produce favorable outcomes based on the relationships students form with community members and the nature of the interactions. Positive attitude change is most likely to occur when student interactions with individuals who are different from them have the following characteristics: (a) equal status of groups, (b) common goals, (c) contradiction of stereotypes, (d) long-term contact, and (e) norms against prejudice. If most service-learning experiences and other civic-engagement activities contain these attributes, then those individuals most heavily engaged in these activities are expected to do so, with outcomes that erode stereotypes, prejudice, and discrimination (Bringle, 2017). Thus, according to CMG's conceptual framework and consistent with the finding in Study 1, civic-minded persons were expected to have an "appreciation of and sensitivity to diversity in a pluralistic society" (Steinberg et al., 2011, p. 22), and it was expected that CMG scores would be associated with non-prejudicial attitudes.

In addition to diversity issues, according to the CMG conceptual framework, civic-minded persons were expected to have confidence in their communication and listening skills and the ability to work with others, especially diverse others. This expectation implicates a variety of social skills and those scoring higher on CMG were expected to score higher on a general assessment of confidence in social skills. Thus, the research question for Study 2 was, To what extent is the CMG Scale correlated with scales that measure the following constructs: Non-Prejudical Attitudes and Self-Confidence in Social Competence?

\section{Methods}

Sample. Study 2 employed the second half of the stratified random sample of undergraduate and graduate students $(n=1,772)$ enrolled at IUPUI. They were contacted in the same manner and given the same instructions as participants in Study 1. Additionally, to over-sample civically engaged persons, eight students were approached in the Center for Service and Learning common area and asked to complete the survey. The survey was confidential; although identifying information was collected to randomly draw a winner of $\$ 100$ from among the survey participants, that information was disaggregated from the data analyses and reports. The only criteria for participation was that respondents were college students 18 years or older. A total of 250 respondents $(69 \%$ female, $31 \%$ male) completed the questionnaire. Fourteen percent of respondents were first-year students, $15 \%$ were second-year students, $14 \%$ were third-year students, $16 \%$ were seniors, $37 \%$ were graduate students, and 4\% were non-degree students. Seventy-three percent of the respondents were Caucasian students, and $90 \%$ were commuter students. The mean age was 29 , and the median age was 26.

Questionnaire. As in Study 1, the questionnaire in Study 2 included single items measuring some demographic information, frequency of political involvement during the previous four years (e.g., worked on political campaign, assisted with voter registration), community involvement 
through campus organizations or clubs, service through community organizations, and the number of service-learning courses taken.

Universal Orientation Scale. The Universal Orientation Scale (Phillips \& Ziller, 1997) consists of 20 items on a 5-point response scale (Does not describe me to Describes me very well) that measures non-prejudice by determining the extent to which respondents note similarities between themselves and others. The UOS contains both positive (UOSpos) and negative (UOSneg) items regarding this orientation. A factor analysis in Study 2 revealed two factors that corresponded to the positive items (e.g., "I can see myself fitting into many groups") and negative items (e.g., "When I first meet someone I tend to notice differences between myself and the other person"). Based on the results of the factor analysis, the items were split into two measures: UOSpos consisted of 12 items (coefficient alpha $=.73$ ), and UOSneg consisted of eight items (coefficient alpha $=.77$ ).

Texas Social Behavior Inventory. The short Form A of the Texas Social Behavior Inventory (TSBI-Form A; Helmreich \& Stapp, 1974) consists of 16 items on a 5-point response scale (Not at all characteristic of me to Very much characteristic of me). Items ask respondents about issues related to their confidence in social situations and measure their self-esteem and social competence (sample item: "I feel confident of my social behavior"). This scale had a coefficient alpha of .85 in the current research.

\section{Results}

Bivariate correlations were computed to assess the relationships between CMG and TSBI, UOSpos, UOSneg, service-learning courses, age, gender, and current college class (see Table 3). UOSpos was a significant correlate of $\mathrm{CMG}$, indicating that those who scored higher on CMG also reported greater levels of perceived similarities between themselves and other people (non-prejudice). TSBI was a significant correlate of $\mathrm{CMG}$, indicating that those who scored higher on CMG reported higher levels of self-esteem in their social competence. Finally, the number of service-learning courses taken was also significantly correlated with CMG.

Table 3. Intercorrelations for CMG, UOSpos, TSBI, and Service-Learning Courses in Study 2

\begin{tabular}{lcccccccc}
\hline Measure & $\mathbf{1}$ & $\mathbf{2}$ & $\mathbf{3}$ & $\mathbf{4}$ & $\mathbf{5}$ & $\mathbf{6}$ & $\mathbf{7}$ & $\mathbf{8}$ \\
\hline 1. CMG & - & & & & & & & \\
2. UOSpos & $.35^{* *}$ & - & & & & & & \\
3. TSBI & $.23^{* *}$ & .09 & - & & & & \\
4. SL Courses & $.18^{* *}$ & .08 & $.14^{*}$ & - & & & \\
5. Age & .03 & .01 & $.25^{* *}$ & .10 & - & & \\
6. UOSneg & .01 & -.07 & $.25^{* *}$ & .01 & .12 & - & & \\
7. College Class & .10 & -.02 & $.17^{* *}$ & $.15^{*}$ & $.46^{* *}$ & .10 & - & \\
8. Gender & .10 & -.01 & -.01 & $.19^{* *}$ & -.05 & .01 & -.07 & - \\
\hline
\end{tabular}

Note. ${ }^{*} p<.05,{ }^{* *} p<.01$. For all correlations, $d f=230$.

A stepwise multiple regression was performed, with $\mathrm{CMG}$ as the dependent variable and UOSpos, TSBI, number of service-learning courses, age, UOSneg, current college class, and gender as predictors. See Table 4 for details on the regression analysis (note: only significant variables are included in the table). UOSpos, TSBI, and the number of service-learning courses taken were independent predictors of CMG. 
10 International Journal of Research on Service-Learning and Community Engagement

Table 4. Stepwise Regression Analysis Summary for Variables Predicting CMG in Study 3

\begin{tabular}{lcccccc}
\hline \multirow{2}{*}{ Variable } & \multicolumn{2}{c}{ Step 1 } & \multicolumn{2}{c}{ Step 2 } & \multicolumn{2}{c}{ Step 3 } \\
\cline { 2 - 7 } & B & $\boldsymbol{\beta}$ & B & $\boldsymbol{\beta}$ & B & $\boldsymbol{\beta}$ \\
\hline Constant & $2.02^{* *}$ & & $1.05^{*}$ & & $.975^{*}$ & \\
UOSpos & $.633^{* *}$ & .36 & $.597^{* *}$ & .34 & $.575^{* *}$ & .33 \\
TSBI & & & $.305^{*}$ & .20 & $.274^{*}$ & .18 \\
SL Courses & & & & & $.147^{*}$ & .14 \\
$R^{2}$ & .129 & & .168 & & .168 & \\
F & $34.05^{* *}$ & $23.09^{* *}$ & & $17.32^{* *}$ & \\
$\Delta R^{2}$ & .129 & & .039 & & .018 & \\
$\Delta F$ & $34.05^{* *}$ & $10.70^{* *}$ & & $4.98^{*}$ & \\
\hline
\end{tabular}

Note. $* \mathrm{p}<.05 . * * \mathrm{p}<.001$

\section{Discussion}

Study 2 provides additional support for the nomological network of CMG. The finding that CMG correlated with positive non-prejudicial thinking converges with the finding in Study 1 for Diversity and supports the inclusion of "understanding the importance of, and the ability to work with, others from diverse backgrounds; also appreciation of and sensitivity to diversity in a pluralistic society" (Steinberg et al., 2011, p. 22) as attributes of CMG. This, in turn, should contribute positively to "ability to work with others, including those with diverse opinions, and work across differences to come to an agreement or solve a problem" (p. 22). This second attribute is also consistent with the finding that $\mathrm{CMG}$ scores were associated with higher levels of the extent to which respondents felt self-assured in social situations and perceived social competency when interacting with others.

\section{General Discussion}

The findings for both research studies converge with the findings of Steinberg et al. (2011) and Bringle and Wall (in press) by providing encouraging results for the validity of CMG's nomological network and the construct validity of the CMG Scale. This positions CMG as a viable candidate for further use in assessing students' civic outcomes, evaluation of service-learning courses and cocurricular service programs, and research on civic outcomes. The factor analysis reported in Steinberg et al. (2011) and the coefficient alphas in all of the research support the characterization of CMG's nomological network as a set of interconnected and cohesive attributes. Although the evidence for the individual components of $\mathrm{CMG}$ is distributed across the current research as well as Steinberg et al. (2011) and Bringle and Wall (in press), Table 5 summarizes the accumulated evidence that supports the meaningfulness of CMG's nomological network for eight of the 10 components that have been included in research to date. 
Table 5. Cumulative Evidence for Components of the Civic-Minded Graduate Nomological Network

\begin{tabular}{|c|c|}
\hline Components & Evidence \\
\hline \multicolumn{2}{|l|}{ Knowledge } \\
\hline Volunteer Opportunities & $\begin{array}{l}\text { Bringle \& Wall (in press): Volunteered at } \\
\text { Community Organizations }\end{array}$ \\
\hline Academic Knowledge and Technical Skills & $\begin{array}{l}\text { Bringle \& Wall (in press): VFI-Understanding; VFI- } \\
\text { Careers }\end{array}$ \\
\hline \multicolumn{2}{|l|}{ Contemporary Social Issue } \\
\hline \multicolumn{2}{|l|}{ Skills } \\
\hline Communication and Listening & $\mathrm{S}_{2}: \mathrm{TSBI} ; \mathrm{UOSpos}$ \\
\hline Diversity & $\mathrm{S}_{1}$ : Openness to Diversity and Challenge; $\mathrm{S}_{2} \mathrm{UOSpos}$ \\
\hline Consensus-Building & $\mathrm{S}_{1}$ : Openness to Diversity and Challenge \\
\hline \multicolumn{2}{|l|}{ Dispositions } \\
\hline Valuing Community Engagement & $\begin{array}{l}\text { Steinberg et al. (2011): Morton's Integrity; Bringle } \\
\& \text { Wall (in press): VFI-Values; } \mathrm{S}_{1} \text { : Principle of } \\
\text { Care }\end{array}$ \\
\hline Self-Efficacy & $\mathrm{S}_{1}:$ Self-Efficacy \\
\hline \multicolumn{2}{|l|}{ Social Trustee of Knowledge } \\
\hline \multicolumn{2}{|l|}{ Behavioral Intentions } \\
\hline Community Service in the Future & $\begin{array}{l}\text { Bringle \& Wall (in press): Civic Identity; Interest in } \\
\text { Three Types of Service; } \mathrm{S}_{1} \text { : Interest in Charity } \\
\text { and Advocacy }\end{array}$ \\
\hline
\end{tabular}

Note. $\mathrm{S}_{1}=$ Study 1 in current research; $\mathrm{S}_{2}=\mathrm{Study} 2$ in current research

Bringle et al. (2015) identified civic identity as a superordinate goal for civic engagement, but their conceptualization of civic identity was limited to the overlap of civic domains and self. CMG is a broader conceptualization because it includes how educational activities inform and contribute to personal growth and civic growth, and how education can provide individuals with a focused sense of civic direction and purpose. Bringle and Wall (in press) found that CMG was correlated with both student identity and civic identity. Therefore, $\mathrm{CMG}$ can be considered a preferable superordinate construct for civic-engagement outcomes that encompasses certain knowledge, skills, dispositions, and behavioral intentions in the civic domain. Steinberg et al. (2011) referred to the CMG construct as the "north star" because it provides a set of common learning objectives that can guide the design, implementation, and assessment of curricular and co-curricular service programs (Bringle et al., in press; Bringle et al., 2011). Because CMG is broad and multifaceted, each of its components may not be equally relevant to a particular service-learning course or to a civically oriented co-curricular program with learning objectives. Nevertheless, CMG can be viewed as a broad set of aspirational outcomes for the cumulative effects of various civically oriented courses, sequences of courses, and civic programs in higher education, either individually or in aggregate. Furthermore, because the components of CMG are viewed as coherent and interdependent, experiences that focus on only some of the components may produce effects on other components. For example, service-learning courses and civically oriented co-curricular programs that have a strong emphasis on volunteering 
and familiarity with the nonprofit sector may influence students' motives for civic engagement, or vice versa. However, the possibility of these generalization effects from one attribute of CMG nomological network to other attributes needs to be examined in future research.

CMG is not exhaustive of all possible civic outcomes (Torney-Purta et al., 2015) but should be understood as sampling civic outcomes. Nevertheless, CMG can provide a conceptual framework for summarizing some ways students have civically benefited or not benefited from a specific civic experience or multiple civic experiences. The CMG Scale can be tailored to a specific research question for a specific collegiate experience (e.g., the items can focus on a particular service-learning course or civic program), a particular institution's courses and programs (as in Steinberg et al., 2011), or cumulative collegiate experiences (e.g., the items can focus on all collegiate experiences, as in this research and Bringle \& Wall, in press). As such, it can serve as a representative sample of some key aspects of civic growth. In the case that a service-learning course or civic program has specific outcomes not included in the CMG conceptual framework (e.g., social justice, environmental stewardship in a geology course focused on the environment), then a separate measure can be used for that particular outcome. Nevertheless, even in that instance, also evaluating CMG can broaden the perspective for how the students have grown civically beyond a specific civiclearning outcome (Bringle et al., in press).

The CMG Scale was common across these two studies, Steinberg et al. (2011) and Bringle and Wall (in press). As predicted, eight of the attributes that were posited to be related to CMG nomological network were found to be significant correlates of CMG. This is viewed as an important step in the validation of the CMG nomological network and the CMG Scale. Although the CMG Scale was used exclusively in this research, practitioners and researchers are not limited to this selfreport scale. Further, the CMG Interview protocol and rubric, as well as the written CMG Narrative and rubric used in Steinberg et al. (2011), can be considered as potentially providing more authentic evidence or alternative evidence of the CMG construct. Because the results of all of the research correlated the CMG Scale with other self-report, paper-and-pencil scales, there may be common method variance contributing to the results, and the research should be replicated with other forms of measurement to ensure that converging results are obtained.

In addition, the correlations that have been obtained should be expected because some CMG Scale items contain references to topics measured with the scales in the current research. For example, the CMG Scale has the following item: "My college experiences have helped me realize that I prefer to work in settings in which I interact with people who are different from me." The Openness to Diversity and Challenge Scale has the item, "I enjoy having discussions with people whose ideas and values are different from my own." The CMG Scale has the item, "Because of my college experiences, I intend to be involved in volunteer service after I graduate." The Principle of Care scale contains the item, "Personally assisting people in trouble is very important to me." On the one hand, it is understandable that the CMG Scale correlated with measures of constructs that are explicitly or implicitly in the CMG self-report scale's item content. On the other hand, there are only one or two items that measure each CMG attribute in the CMG Scale, and the independent measures of other constructs in this research are not necessarily civic in nature (e.g., general measure of selfefficacy). Therefore, it is noteworthy that all of the measures in these two studies, Bringle and Wall (in press), and Steinberg et al. (2011) had the expected bivariate correlations. In addition, it is significant that, frequently, the stepwise multiple regression results identified some of these measures as independent (i.e., non-redundant) predictors of CMG when they were contained in the same study.

\section{Implications for Practice}

CMG can serve as a common framework for curricular and co-curricular service programs. Bringle et al. (2011) identified the following institutional functions that $\mathrm{CMG}$ provides:

(a) common understanding of and appreciation by the staff of the strengths of individual 
programs; (b) a delineation of knowledge, skills, and dispositions associated with civicallyoriented programs; (c) development of assessment procedures (scale, narrative analysis with rubrics, interviews) to evaluate CMG (Steinberg et al., 2011); (d) the capacity to evaluate CSL programs and provide feedback to coordinators for program improvements; (e) a framework for enhancing civic learning in service-learning courses by more intentionally designing course activities in terms of CMG elements; (f) a procedure for obtaining institutional assessment of students' civic outcomes across majors; (g) a way of communicating and discussing civic learning outcomes with various internal and external audiences; (h) a means for conducting research associated with civic growth that can evaluate components of developmental models as programmatic or mediating variables; (i) thinking and planning more intentionally and coherently about civic development; and (j) deepening partnerships with and contributions to the community. (p. 22)

Thus, CMG can operate to assess civic growth at the level of the individual, course, program, department, school, institution, or across multiple institutions. For example, CMG can be the basis for an exit assessment of graduating students to provide a summary of civic outcomes for the institution as a whole, which could be used in accreditation, award applications, and grant proposals. Internally, such information could profile the civic outcomes of students in different departments or schools (Bringle et al., in press).

The number of service-learning courses taken correlated consistently with CMG in this research, in Steinberg et al. (2011), and in Bringle and Wall (in press). However, these correlations do not establish that involvement in service-learning courses is the origin of higher civic-mindedness because, among other explanations, they do not take into account self-selection of students into civically oriented experiences (e.g., service-learning courses), avoidance of civic activities by some, or differential dropout from these experiences by the civically unmotivated. Bringle and Wall found that enhancing understanding was an important motive for those with higher CMG scores and that CMG was correlated with identity as a student. These findings highlight that educationally meaningful community service may promote development of civic-mindedness through servicelearning. Bringle and Wall suggested that increasing civic-mindedness is likely to develop through high-quality service-learning courses that allow students to explore aspects of their identity and explore issues related to power and privilege through careful selection of community-based activities, key readings, classroom discussions, democratic partnerships, and reflection activities. The findings in the current research on positive attitudes toward diversity and lack of prejudicial thinking for those scoring higher on CMG are consistent with King, Baxter Magolda, and Massé's (2011) finding that participants who used more internal meaning making exhibited advanced levels of intercultural maturity, defined as "how people become increasingly capable of understanding and acting in ways that are interculturally aware and appropriate" (King \& Baxter Magolda, 2005, p. 573). Service-learning instructors should explore these factors as mechanisms for further integrating a student's identity with both the academic and civic domains.

Concerning the nature of the service activities, Bowman's (2011) meta-analysis found that faceto-face interactions with diverse groups resulted in favorable and significant effects on civic attitudes, behavioral intentions, and behaviors compared to classroom-based educational experiences and co-curricular activities. Similarly, Levine's (2013) research found that simply involving students in community-service activities was insufficient for developing civic learning and civic skills; they must also be involved in collaborative relationships in the civic realm. Partnerships between students and community members that contain democratic qualities, (e.g., just, inclusive, participatory, reciprocal; Saltmarsh et al., 2009) are critical and necessary for civic growth by all participants in civic engagement. Drawing from Knefelkamp's (2008) model for developing civic identity, civicengagement activities and programs should not only involve face-to-face interactions but also opportunities for the partners to engage in complex intellectual tasks, consider ethical aspects of their activities, provide opportunities for empathic understanding across differences, and take part in 
active reflection. This suggests that intentionally involving students in genuinely collaborative crosscultural experiences, as well as intentionally focusing on the nature of these interactions in ways that can support civic growth, is important to the outcomes of service-learning courses and co-curricular civic programs for developing CMG. Experimental research by Brown (2011) found that participation of students in service-learning activities that involved face-to-face interactions with community members led to a decline in social dominance orientation, which is associated with several oppressive attitudes, including sexism and racism. Brown, Wymer, and Cooper (2016) found, in a randomized control-group study, that autonomy-oriented helping (vs. dependency-oriented helping) resulted in more positive views of social equality. This suggests a risk of service-learning experiences reinforcing hierarchical relationships between students and others, rather than more equal relationships that involve students working with others in communities.

Axlund, Renner, and Cress (2009) found that, although 38\% of faculty reported discussing civic responsibility or local political issues in class, only $24 \%$ assigned readings focused on civic-learning goals. Thus, few faculty are intentionally focusing students' attention and analysis on issues related to the development of broad civic-mindedness. Astin and colleagues (2000) found that servicelearning facilitated an increased sense of personal efficacy, awareness of the world and personal values, and engagement in the classroom experience. Their research also identified the importance of reflection in connecting service experiences with course material. Thus, service-learning can provide a means for more faculty to focus on civic-learning goals. Bowman, Brandenberger, Hill, and Lapsley (2011) identified taking ethnic studies courses and racial/cultural awareness workshops as being related to a stronger orientation toward prosocial goals during college and to adult well-being, suggesting that later well-being may be mediated through increasing prosocial goal commitment during college.

Research has found that the general climate of a campus can contribute to students' civic growth (Janke \& Domagal-Goldman, 2017). For example, student perceptions of a nondiscriminatory racial environment on campus, the diversity of students' acquaintances, and conversations with others were positively associated with openness to diversity (Whitt et al., 2001) as were students' perceptions of instructors' valuing a wide range of ideas and perspectives and instructors' advocacy for the respect of diverse ideas and points of view (Ryder, Reason, Mitchell, Gillon, \& Hemer, 2015). Thus, both pedagogical practice and campus climate can contribute to developing CMG.

Bringle et al. (2011) posited that CMG is not only relevant as an educational outcome to students involved in civic engagement but also for faculty, administrators, staff at nonprofit organizations, and community residents (Clayton, Bringle, Senor, Huq, \& Morrison, 2010). This suggests taking seriously the development of civic-mindedness among each of these constituencies and intentionally designing programs (e.g., in-service education, formal courses, continuing education courses, workshops), acquiring resources (e.g., grants, specialized staff) and developing infrastructure (e.g., programs, groups of individuals, a task force) that reflect the values of democratic processes, working with diverse others in collaborative ways; and civic growth among a broad range of constituencies (Bringle et al. 2011; Clayton et al., 2010). Thus, inherent in any discussion and examination of civic-engagement outcomes is the nature of the partnerships as a precursor to civic outcomes among different constituencies (Bringle \& Clayton, 2013) as well as the nature of developed partnerships as a civic outcome in its own right.

\section{Future Research}

Each of the implications for practice mentioned earlier provides a hypothesis that can be a basis for future research to determine the nature of the expected effect and to clarify which aspects of practice (e.g., which course components, which civic program components) contribute to the expected civic outcomes and for whom. For example, Hatcher, Bringle, and Hahn (2017a) identified six attributes of service-learning courses that can vary in intensity and that can be related to student outcomes: degree of (a) reciprocity in community partnerships, (b) integration of community-engaged activities 
and academic content, (c) emphasis on civic-learning outcomes, (d) diversity experiences, (e) critical reflection guided by student learning objectives, and (f) use of assessment for course improvement. These course attributes provide a basis for evaluating the quality of a service-learning course and for analyzing how overall quality as well as individual course characteristics are related to the development of students' civic-mindedness. The relative importance of these courses characteristics as well as other aspects of the pedagogy (e.g., instructor's experience with the pedagogy, alignment with other principles of good practice, how student characteristics moderate outcomes, campus climate) need to be explored in research on civic-learning outcomes.

Astin, Sax, and Avalos (1999) found that the short-term effects of undergraduate service participation in the affective and cognitive domains persisted nine years after college. In addition, post-graduation effects have been found for political participation (Hillygus, 2005) and volunteering and civic involvement (Astin et al., 1999; Bowman et al., 2015; Keen \& Hall, 2008; Ruiz \& Warchal, 2013). Hatcher's (2008) work on civic-minded professionals suggests that students can also think about the connections between civic and educational domains with regard to their future career plans. Richard et al. (2016) conducted a longitudinal study on alumni of the Bonner Scholars Program and found that the more civic-minded professionals reported a number of greater civic activities and more volunteering. These types of longitudinal, post-graduation outcomes need to be further explored using CMG (Hill, Pasquesi, Bowman, \& Brandenberger, 2017).

Future research on CMG should also attend to two limitations of most past research on civic outcomes (Steinberg, Bringle, \& McGuire, 2013): self-selection of students into civically oriented courses and programs, and self-report measures. Concerning self-selection of students, Eyler, Giles, and Braxton (1997) found that students who chose service-learning differed from those who did not on pre-service attitudes, skills, values, and understanding of social issues. This issue is important because past research does not provide adequate guidance for practitioners to understand how a civic program and service-learning course might be designed differently for students for whom civicmindedness is relatively low. This issue is acute for future research that will directly confront identifying which factors contribute to the development of CMG among those students who are initially low on CMG. Research can also contribute to understanding how to develop intrinsic motivation among those students who lack motivation for civic behaviors, change attitudes among students who do not have positive civic attitudes, and engage students who are resistant to participating in civic activities (Bringle, 2017). This illustrates how future research has much to offer by evaluating various theoretical perspectives for informing the developmental and change processes that may occur in a service-learning course and result in enhanced civic outcomes (Bringle et al., 2015; Hatcher, Bringle, \& Hahn, 2017b). An asset of the two studies reported in this research is that they, in part, included a broader sample of students beyond those who enrolled in service-learning courses or who were part of a civically oriented program.

Concerning the use of self-report measures, as in most research on civic outcomes (Hemer \& Reason, 2017), this research used self-report measures for all constructs, including CMG. Self-report measures are known to suffer from inaccuracies, not accurately reflecting processes that determined outcomes, and being based on inaccurate or biased memories (Kolek, 2013; Steinberg et al., 2013). Self-assessments of skill, character, and learning are particularly flawed (Bowman \& Seifert, 2011; Dunning, Heath, \& Suls, 2004). Fortunately, Steinberg et al. (2011) provided alternative measures for measuring $\mathrm{CMG}$ that can be used in subsequent research. In addition, alternative types of measures of other constructs (e.g., knowledge, skills, attitudes, authentic evidence of learning) should be included in subsequent research on CMG and related constructs. 


\section{References}

Allport, G. W. (1954). The nature of prejudice (Abr. ed.). Garden City, NY: Doubleday.

Astin, A. W., \& Sax, L. J. (1998). How undergraduates are affected by service participation. Journal of College Student Development, 39, 251-263.

Astin, A. W., Sax, L. J., \& Avalos, J. (1999). The long-term effects of volunteerism during the undergraduate years. Review of Higher Education, 21(2), 187-202.

Astin, A. W., Vogelgesang, L. J., Ikeda, E. K., \& Yee, J. A. (2000). How service learning affects students. Higher Education, 144. Retrieved from https://digitalcommons.unomaha.edu/ slcehighered/144/

Axlund, R., Renner, T., \& Cress, C. (2009). Faculty engagement in service-learning \& communitybased research: WRCCC Survey data summary. Bellingham, WA: Washington Campus Compact.

Bandura, A. (1977). Self-efficacy: Toward a unifying theory of behavioral change. Psychological Review, 84(2), 191-215.

Batson, C. D., \& Ahmad, N. (2009). Using empathy to improve attitudes and relations. Social Issues and Policy Review, 3(1), 141-177. https://doi.org/10.1111/j.1751-2409.2009.01013.x

Battistoni, R. (2002). Civic engagement across the curriculum. Providence, RI: Campus Compact.

Bekkers, R., \& Ottoni-Wilhelm, M. (2016). Principle of care and giving to help people in need. European Journal of Personality, 30(3), 240-257.

Bowman, N. A. (2011). Promoting participation in a diverse democracy: A meta-analysis of college diversity experiences and civic engagement. Review of Educational Research, 81(1), 29-68.

Bowman, N. A., Brandenberger, J. W., Hill, P. L., \& Lapsley, D. K. (2011). The long-term effects of college diversity experiences: Well-being and social concerns 13 years after graduation. Journal of College Student Development, 52(3), 729-739. DOI: 10.1353/csd.2011.0075

Bowman, N. A., Park, J. J., \& Denson, N. (2015). Student involvement in ethnic student organizations: Examining civic outcomes 6 years after graduation. Research in Higher Education, 56, 127-145.

Bowman, N. A., \& Seifert, T. A. (2011). Can college students accurately assess what affects their learning and development? Journal of College Student Development, 52(3), 270-290.

Brandenberger, J. W., \& Bowman, N. A. (2015). Prosocial growth during college: Results of a national study. Journal of Moral Education, 44(3), 328-345. http://dx.doi.org/10.1080/03057240.2015.1048792

Bringle, R. G. (2017). Social psychology and civic outcomes. In J. A. Hatcher, R. G. Bringle, \& T. W. Hahn (Eds.), Research on service learning and student civic outcomes: Conceptual frameworks and methods (pp. 69-89). Sterling, VA: Stylus.

Bringle, R. G., Brown, L., Hahn, T. W., \& Studer, M. (in press). Pedagogies and civic programs to develop competencies for democratic culture and civic learning outcomes. Bordon. Revista de Pedagogia.

Bringle, R. G., \& Clayton, P. H. (2013). Conceptual frameworks for partnerships in service learning. In P. Clayton, R. Bringle, \& J. Hatcher (Eds.). Research on service learning: Conceptual frameworks and assessment Vol. 2B: Communities, institutions, and partnerships (pp. 539571). Arlington, VA: Stylus.

Bringle, R. G., Games, R., \& Malloy, E. A. (Eds.) (1999). Colleges and universities as citizens. Needham Heights, MA: Allyn \& Bacon.

Bringle, R. G., Hatcher, J. A., \& MacIntosh, R. (2006). Analyzing Morton's typology of service paradigms and integrity. Michigan Journal of Community Service Learning, 13(1), 5-15.

Bringle, R. G., Hedgepath, A., \& Wall, E. (2018). "I am so angry I could . . help!" The nature of empathic anger. International Journal of Research on Service-Learning and Community Engagement, 6(1), Article 3. 
Bringle, R. G., \& Steinberg, K. S. (2010). Educating for informed community involvement. American Journal of Community Psychology, 46(3-4), 428-441. https://doi.org/10.1007/s10464-010-9340-y

Bringle, R. G., Studer, M. H., Wilson, J., Clayton, P. H., \& Steinberg, K. (2011). Designing programs with a purpose: To promote civic engagement for life. Journal of Academic Ethics, 9(2), 149-164.

Bringle, R. G., \& Wall, E. (in press). Civic-minded graduate: Additional evidence I. Michigan Journal of Community Service Learning.

Brown, M. A. (2011). Learning from service: The effect of helping on helper's social dominance orientation. Journal of Applied Social Psychology, 41(4), 850-871.

Brown, M. A., Wymer, J. D., \& Cooper, C. S. (2016). The counter-normative effects of servicelearning: Fostering attitudes toward social equality through contact and autonomy. Michigan Journal of Community Service Learning, 23(1), 37-44.

Catlett, B. S., \& Proweller, A. (2011). College students' negotiation of privilege in a communitybased violence prevention project. Michigan Journal of Community Service Learning, 18(1), 34-48.

Clary, E. G., Snyder, M., Ridge, R. D., Copeland, J., Stukas, A. A., Haugen, J., \& Miene, P. (1998). Understanding and assessing the motivations of volunteers: A functional approach. Journal of Personality and Social Psychology, 74, 516-530.

Clayton, P. H., Bringle, R. G., Senor, B., Huq, J., \& Morrison, M. (2010). Differentiating and assessing relationships in service-learning and civic engagement: Exploitive, transactional, and transformational. Michigan Journal of Community Service Learning, 16(2), 5-21.

Colby, A., Ehrlich, T., Beaumont, E., \& Stephens, J. (2003). Educating citizens: Preparing America's undergraduates for lives of moral and civic responsibility. San Francisco, CA: Jossey-Bass.

Cronbach, L., \& Meehl, P. (1955). Construct validity in psychological tests. Psychological Bulletin, $52,281-302$.

Dewey, J. (1938). Experience and education. New York, NY: Macmillan.

Dunning, D., Heath, C., \& Suls, J. M. (2004). Flawed self-assessment: Implications for health, education, and the workplace. Psychological Science in the Public Interest, 5(3), 69-106.

Eisenberg, N. (1982). The development of reasoning regarding prosocial behavior. In N. Eisenberg (Ed.), The development of prosocial behavior (pp. 219-249). New York, NY: Academic Press.

Erickson, J. A., \& O’Connor, S. E. (2000). Service-learning: Does it promote or reduce prejudice? In C. O'Grady (Ed.), Integrating service learning and multicultural education in colleges and universities (pp. 59-70). Mahwah, NJ: Erlbaum Associates.

Eyler, J. (2000). What do we most need to know about the impact of service-learning on student learning? Michigan Journal of Community Service Learning, 2000(Fall), 11-17.

Eyler, J., \& Giles, D. E., Jr. (1999). Where's the learning in service-learning? San Francisco, CA: Jossey-Bass.

Eyler, J. S., \& Giles, D. E., Jr., \& Braxton, J. (1997). The impact of service-learning on college students. Michigan Journal of Community Service Learning, 4, 5-15.

Hatcher, J. A. (2008). The public role of professionals: Developing and evaluating the civic-minded professional scale (Doctoral dissertation). Retrieved from http://scholarworks.iupui.edu/handle/1805/1703

Hatcher, J. A., Bringle, R. G., \& Hahn, T. W. (2017a). Introduction to research on service learning and student civic outcomes. In J. A. Hatcher, R. G. Bringle, \& T. W. Hahn (Eds.), Research on service learning and student civic outcomes: Conceptual frameworks and methods (pp. 3-24). Sterling, VA: Stylus.

Hatcher, J. A., Bringle, R. G., \& Hahn, T. W. (Eds.). (2017b). Research on service learning and student civic outcomes: Conceptual frameworks and methods. Sterling, VA: Stylus. 
18 | International Journal of Research on Service-Learning and Community Engagement

Helmreich, R., \& Stapp, J. (1974). Short forms of the Texas Social Behavior Inventory (TSBI), an objective measure of self-esteem. Bulletin of the Psychonomic Society, 4(5A), 473-475.

Hemer, K. M., \& Reason, R. D. (2017). Student civic outcomes in higher education. In J. A. Hatcher, R. G. Bringle, \& T. W. Hahn (Eds.), Research on service learning and student civic outcomes: Conceptual frameworks and methods (pp. 25-43). Sterling, VA: Stylus.

Hill, P. L., Pasquesi, K., Bowman, N. A., \& Brandenberger, J. W. (2017). Longitudinal research and student civic outcomes. In J. A. Hatcher, R. G. Bringle, \& T. W. Hahn (Eds.), Research on service learning and student civic outcomes: Conceptual frameworks and methods (pp. 283302). Sterling, VA: Stylus.

Houle, B. J., Sagarin, B. J., \& Kaplan, M. F. (2010). A functional approach to volunteerism: Do volunteer motives predict task preference. Basic and Applied Social Psychology, 27, 337344.

Janke, E. M., \& Domagal-Goldman, J. M. (2017). Institutional characteristics and student civic outcomes. In J. Hatcher, R. Bringle, \& T. Hahn (Eds.), Research on service learning and student civic outcomes (pp. 261-281). Sterling, VA: Stylus.

Jones, S. R., \& Hill, K. (2001). Crossing High Street: Understanding diversity through community service-learning. Journal of College Student Development, 42(3), 204-216.

Keen, C., \& Hall, K. (2008). Post-graduation service and civic outcomes for high financial need students of a multi-campus, co-curricular service-learning college program. Journal of College and Character, 10, 1-15.

King, P. M., \& Baxter Magolda, M. B. (2005). A developmental model of intercultural maturity. Journal of College Student Development, 46, 571-592.

King, P. M., Baxter Magolda, M. B., \& Masse, J. (2011). Maximizing learning from engaging across difference: The role of anxiety and meaning making. Equity and Excellence in Education, 44(4), 468-487.

Knefelkamp, L. L. (2008). Civic identity: Locating self in community. Diversity and Democracy, $11(2), 1-3$.

Kolek, E. A., (2013). Can we count on counting? An analysis of the validity of community engagement survey measures. International Journal of Research on Service-Learning and Community Engagement, 1(1), 92-108.

Levine, P. (2013, February). A defense of higher education and its civic mission. Plenary address at the Pathways to Achieving Civic Engagement Conference, Elon, NC.

Moely, B. E., Furco, A., \& Reed, J. (2008). Charity and social change: The impact of individual preferences on service-learning outcomes. Michigan Journal of Community Service Learning, 15(1), 37-48.

Morton, K. (1995). The irony of service: Charity, project and social change in service-learning. Michigan Journal of Community Service Learning, 2(1), 19-32.

National Task Force on Civic Learning and Democratic Engagement. (2012). A crucible moment: College learning and democracy's future. Washington, DC: Association of American Colleges and Universities.

Pascarella, E. T., Edison, M., Nora, A. Hagedorn, L. S., \& Terenzini, P. T. (1996). Influences on students' openness to diversity and challenge in the first year of college. Journal of Higher Education, 67(2), 174-195. Retrieved from http://www.jstor.org/stable/2943979.

Pascarella, E., Martin, G. L., Hanson, J. M., \& Trolian, T. L. (2014). Effects of diversity experiences on critical thinking skills over four years of college. Journal of College Student Development, 55(1), 86-92.

Percy, L., Zimpher, N., \& Brukardt, M. (Eds.). (2006). Creating a new kind of university. Institutionalizing community-university engagement. Bolton, MA: Anker.

Pettigrew, T. F., \& Tropp, L. R. (2008). How does intergroup contact reduce prejudice? Metaanalytic tests of three mediators. European Journal of Social Psychology, 38, 922-934. 
Phillips, S. T., \& Ziller, R. C. (1997). Toward a theory and measure of the nature of nonprejudice. Journal of Personality and Social Psychology, 72(2), 420-434. https://doi.org/10.1037/0022$\underline{3514.72 .2 .420}$

Pratto, F., Sidanius, J., Stallworth, L., \& Malle, B. (1994). Social dominance orientation: A personality variable predicting social and political attitudes. Journal of Personality and Social Psychology, 67(4), 741-763. http://dx.doi.org/10.1037/0022-3514.67.4.741

Reeb, R. N. (2006). The Community Service Self-Efficacy Scale: Further evidence of reliability and validity. In R. Reeb (Ed.), Community action research: Benefits to community members and service providers (pp. 97-113). New York, NY: Haworth Press.

Reeb, R. N., Katsuyama, R. M., Sammon, J. A., \& Yoder, D. S. (1998). The Community Service Self-Efficacy Scale: Evidence of reliability, construct validity, and pragmatic utility. Michigan Journal of Community Service Learning, 5(1), 48-57.

Richard, D., Keen, C., Hatcher, J. A., \& Pease, H. A. (2016). Pathways to adult civic engagement: Benefits of reflection and dialogue across difference in higher education service-learning programs. Michigan Journal of Community Service Learning, 23(1), 60-74.

Ruiz, A., \& Warchal, J. (2013). Long-term impact of service-learning on alumni volunteer service activities. In P. Lin \& M. Wiegand (Eds.), Service-learning in higher education: Connecting the global to the local (pp. 255-264). Indianapolis, IN: University of Indianapolis Press.

Ryder, A. J., Reason, R. D., Mitchell, J. J., Gillon, K., \& Hemer, K. M. (2015). Climate for learning and students' openness to diversity and challenge: A critical role for faculty. Journal of Diversity in Higher Education, 9(4), 339-352.

Saltmarsh, J., \& Hartley, M. (Eds.). (2012). "To serve a larger purpose”: Engagement for democracy and the transformation of higher education. Philadelphia, PA: Temple University Press.

Saltmarsh, J., Hartley, M., \& Clayton, P. H. (2009). Democratic engagement white paper. Boston, MA: New England Resource Center for Higher Education.

Sanders, M. J., Oss, T. V., \& McGeary, S. (2016). Analyzing reflections in service learning to promote personal growth and community self-efficacy. Journal of Experiential Education, 38(1), 73-88.

Sherer, M., Maddux, J. E., Mercandante, B., Prentice-Dunn, S., Jacobs, B., \& Rogers, R. W. (1982). The Self-Efficacy Scale: Construction and validation. Psychological Reports, 51(2), 663 671. https://doi.org/10.2466/pr0.1982.51.2.663

Steinberg, K., Bringle, R. G., \& McGuire, L. E. (2013). Attributes of quality research in service learning. In P. H. Clayton, R. G. Bringle, \& J. A. Hatcher (Eds.), Research on service learning: Conceptual frameworks and assessment. Vol. 2A: Students and faculty (pp. 2753). Arlington, VA: Stylus.

Steinberg, K. S., Hatcher, J. A., \& Bringle, R. G. (2011). Civic-minded graduate: A north star. Michigan Journal of Community Service Learning, 18(1), 19-33.

Teranishi, C. S. (2007). Impact on experiential learning on Latino college students' identity, relationships, and connectedness to the community. Journal of Hispanic Higher Education, $6(1), 52-72$.

Torney-Purta, J., Cabrera, J. C., Roohr, K. C., Liu, O. L., \& Rios, J. A. (2015). Assessing civic competency and engagement in higher education: Research background, frameworks, and directions for next-generation assessment. ETS Research Report Series, 2015(2), 1-48.

Wang, Y., \& Jackson, G. (2005). Forms and dimensions of civic involvement. Michigan Journal of Community Service Learning, 11(2), 39-48.

Whitt, W. J., Edison, M. I., Pascarella, E. T., Terenzini, P. T., \& Nora, A. (2001). Influences on students' openness to diversity and challenge in the second and third years of college. Journal of Higher Education, 72(2), 172-204. https://doi.org/10.1080/00221546.2001.11778877 
20 | International Journal of Research on Service-Learning and Community Engagement

Wilhelm, M. O., \& Bekkers, R. (2010). Helping behavior, dispositional empathic concern, and the principle of care. Social Psychology Quarterly, 73(1), 11-32.

\author{
About the Authors \\ Robert G. Bringle is Chancellor's Professor Emeritus of Psychology and Philanthropic Studies at \\ Indiana University Purdue University Indianapolis (IUPUI). \\ Thomas W. Hahn is Director of Research and Program Evaluation at the Center for Service and \\ Learning at IUPUI. \\ Julie A. Hatcher is Professor Emeritus in the Lilly Family School of Philanthropy at IUPUI. \\ Correspondence concerning this article should be addressed to Robert G. Bringle at \\ rbringle@iupui.edu.
}

